\title{
Gagnreynd meðferð við áráttu- og práhyggjuröskun hjá börnum og unglingum: Yfirlitsgrein
}

\author{
Guð̃mundur Skarphéðinsson ${ }^{1}$ sálfræðingur, Bertrand Lauth ${ }^{2,3}$ læknir, Urður Njarðvík ${ }^{4}$ sálfræðingur, Tord Ivarsson' læknir
}

\section{ÁGRIP}

Áráttu- og bráhyggjuröskun (ÁPR) hjá börnum og unglingum einkennist af práhyggjukenndum hugsunum og áráttukenndri hegðun eða hugsun. Í pessari yfirlitsgrein er lýst gagnreyndri meðferð við ÁPR meðal barna og unglinga. Leitað var í PubMED að öllum samanburðarrannsóknum, yfirlitsgreinum og klínískum leiðbeiningum. Hugræn atferlismeðferð (HAM) og sérhæfð serótónín-endurupptökuhamlandi lyf (SSRI) eru áhrifarík meðferðarform fyrir börn og unglinga sem koma fyrsta sinn í meðferð. Í samanburðarrannsóknum hefur HAM vinninginn. Rannsóknir á börnum sem svara fyrstu meðferð illa eru takmarkaðar en benda pó til pess að áfram- haldandi HAM og SSRI séu áhrifarík úrræđi fyrir bá sem ekki svara HAM en HAM+SSRI sé áhrifaríkasta úrræðið fyrir pá sem ekki svara SSRI og hafa aldrei verið meðhöndlaðir með HAM. Fyrri rannsóknir eru í samræmi við klínískar leiðbeiningar par sem fyrsta úrræði er HAM pegar aðgengi að kunnáttumönnum í HAM er til stađar. HAM er einnig jafn árangursríkt og SSRI hjá peim sem enn hafa talsverð einkenni eftir 14 vikur. Niðurstöður bentu ekki til pess að HAM+SSRI sé áhrifaríkara en HAM veitt af sérfræðingum. HAM+SSRI er áhrifaríkara en SSRI hjá peim sem ekki hafa svarað SSRI.
${ }^{1}$ Center for Child and Adolescent Mental Health, Austur- og Suður-Noregi

${ }^{2} æ$ ænadeild Háskól íslands, ${ }^{3}$ Landspítala, ${ }^{4}$ sálffræðideild Háskóla Íslands.

Fyrirspurnir:

Guðmundur Skarphéðinsson

gudmundur. skarphedinsso

@r-bup.no

Greinin barst 8. desember 2014 sambykkt til birtingar

15. mars 2016.

Höfundar hafa útfyllt eyðublað̆ um hagsmunatengsl.

\section{Inngangur}

Áráttu- og práhyggjuröskun (ÁPR) einkennist af práhyggjuhugsunum og áráttukenndri hegðun og hugsun. ${ }^{1}$ ÁPR er langvinn geðröskun sem hefur mikil áhrif á starfsgetu. ${ }^{2}$ Hjá börnum er ÁPR í um 20-60\% tilfella eina röskunin en algengustu fylgiraskanir eru kipparaskanir (20-59\%), kvíðaraskanir (19-34\%) og ADHD (8-26\%). ${ }^{3-5}$ Einkennamynd ÁPR (hjá börnum og fullorðnum) er mjög misleit en algengustu einkenni eru práhyggjuhugsanir um smithættu og afleiðingar peirra og árátta sem snýr að pví að koma í veg fyrir smithættu. ${ }^{6}$ Algengi ÁPR meðal barna er frá 0,5-2\%. Fyrsti meðferðarkostur er hugræn atferlismeðferð (HAM) og sérhæfð serótónín-endurupptökuhamlandi lyf (specific serotonin reuptake inhbitors; SSRI). ${ }^{2}$ Prátt fyrir að pessi meðferðarform séu árangursrík, benda rannsóknir til pess að aðeins 20-50\% barna með ÁPR öðlist bata. ${ }^{4,5,7}$ Að auki uppfylla 40\% barna enn greiningarviðmið 1-15 árum eftir að meðferð lýkur ${ }^{8,9}$ og $20 \%$ til viðbótar hafa enn hamlandi einkenni undir greiningarviðmiðum. ${ }^{8}$ Pess vegna er afar mikilvægt að börn með ÁPR, hvort sem pau hafa aldrei pegið meðferð eða verið meðhöndluð einu sinni eða oftar, fái viðeigandi, betri, og/ eða rétta samsetningu af núverandi meðferðarúrræðum.

Lýst er stöðu á gagnreyndum meðferðarúrræðum fyrir börn með ÁPR. Við gerum greinarmun á premur ólíkum hópum barna. Börn sem hafa ekki verið meðhöndluð með fyrsta úrræði (HAM eða SSRI) (treatment-naive), börn sem hafa verið meðhöndluð einu sinni með fyrsta úrræði en hafa svarað pví illa (treatment-resistant) og loks börn með meðferðarpolið ÁpR (sem hvorki hafa svarað HAM né SSRI) (treatmentrefractory).${ }^{10}$ Leitað var í PubMED 10. júní 2015 að eftirfarandi leitarorðum „obsessive-compulsive disorder", "child" og „,adolescent“ og síað eftir eftirfarandi hugtökum "randomized controlled trials", "systematic review", og „meta-analysis“. Einnig lásum við nýlegar yfirlitsgreinar og klínískar leiðbeiningar. ${ }^{2,11-18}$

\section{Gagnreynt fyrsta meðferðarúrræði}

Fyrsta meðferð fyrir ÁPR meðal barna og unglinga er HAM og/eða SSRI. Bandarískar leiðbeiningar mæla með HAM fyrir börn sem eru með væg og miðlungs einkenni og HAM og SSRI saman fyrir börn sem eru með miðlungs og alvarleg einkenni. ${ }^{2}$ Evrópskar leiðbeiningar mæla hins vegar með HAM sem fyrsta vali fyrir öll börn með ÁpR, óháð alvarleika einkenna, en HAM og SSRI fyrir börn sem ekki svara HAM eða vilja ekki taka pátt í HAM. ${ }^{19}$

\section{HAM}

HAM er skammvinn sálfræðimeðferð sem leggur áherslu á hugsun og hegðun sem hjálpar til við að draga úr einkennum ÁPR. Markmiðið er að kenna nýjar aðferðir og viðbrögð við práhyggjuhugsunum. HAM inniheldur hugrænt endurmat (cognitive restructuring) og berskjöldun með svarhömlun (exposure and response prevention). Berskjöldunaræfingar eru oft taldar vera áhrifaríkasti pátturinn., ${ }^{2,20}$ Berskjöldun vísar til pess að útsetja sig eða berskjalda sig fyrir hugsunum, ímyndum, hlutum og aðstæðum sem vekja upp práhyggjuhugsanir og/eða ópægilegar tilfinningar (kvíða, ógeðstilfinning). Svarhömlun felst í að ákveða að beita ekki fyrir sig áráttuhegðun pegar práhyggju- 
hugsanir eða ópægilegar tilfinningar gera vart við sig.. ${ }^{24}$ Niðurstöður nýlegra heildargreininga ${ }^{11,12}$ sýna að HAM er árangursríkara en biðlisti ${ }^{21,25-29}$ (Hedge's g $\left.[\mathrm{g}]=-1,42\right)$, lyfleysa $(\text { pill placebo })^{4}(\mathrm{~g}$ $=-0,96)$, meðferðarleysa (psychotherapy placebo) $(\mathrm{g}=-0,74)$, og SSRI ( $g=-0,39),{ }^{4,32,33}$ Petta pýðir að í lok meðferðar var meðalpátttakandi í HAM með mun lægra skor á The Children's Yale-Brown Obsessive Compulsive Scale (CY-BOCS) ${ }^{34}$ en meðalpátttakandi í samanburðarhópi. Petta samsvarar 46 hundraðstölum (percentile) fyrir biðlista, 33 fyrir lyfleysu, 27 fyrir meðferðarleysu og 15 fyrir SSRI. ${ }^{35}$ HAM er einnig árangursríkt meðal barna allt niður í priggja ára aldur par sem gerð er greinileg aðlögun á pátttöku foreldra í berskjöldunaræfingum..$^{29}$ Klínískar leiðbeiningar mæla með pví að meðferðin taki mið af pví að foreldrar eða öll fjölskyldan taki pátt í meðferðinni. ${ }^{19}$ Nýlegar handbækur hafa tekið mið af pessu og aðlagað mjög greinilega pátttöku foreldra í berskjöldunaræfingum og öðrum hlutum meðferðar. ${ }^{5,729,31}$ HAM fyrir börn með ÁPR krefst mikillar sérhæfni og pjálfunar ef góður árangur á að nást og pví mikilvægt að meðferðaraðilar sem vilja sinna pessari meðferð fái næga sérhæfingu. ${ }^{36}$ Ekki er vitað hversu margir íslenskir meðferðaraðilar geta veitt pessa sérhæfðu meðferð en par sem sálfræðimeðferð er eins og stendur ekki niðurgreidd hafa margir sjúklingar ekki aðgang að henni. Almennt má segja að eina niðurgreidda aðgengi að HAM megi finna á barna- og unglingageðdeild Landspítala og á heilsugæslustöðvum. Foreldrar með börn (undir 18 ára aldri) geta hins vegar sótt um umönnunarbætur til að mæta meðferðarkostnaði. Sálfræðipjónusta er einnig niðurgreidd af sjúkratryggingum fyrir börn yngri en 18 ára ef pau eru í meðferð hjá sálfræðingum sem eru aðilar að rammasamningi sálfræðinga og Sjúkratrygginga Íslands. ${ }^{37}$

Um $30-50 \%$ barna hafa enn hamlandi einkenni prátt fyrir viðunandi meðferð. ${ }^{4,5,7,16}$ pættir sem hafa spáð fyrir um lítinn árangur eru til dæmis alvarleg einkenni í upphafi meðferðar, ${ }^{38-40}$ fylgiraskanir, önnur geðræn einkenni ${ }^{39-41}$ og einnig vandamál innan fjölskyldu (family dysfunction) á borð við að foreldrar og aðrir fjölskyldumeðlimir aðlagi sig og sínar parfir of mikið að einkennum barnsins (high family accommodation) pannig аð barnið sér sig ekki knúið til að minnka einkenni eða taka pátt í meðferð. ${ }^{38,39,42}$ Hins vegar hefur pað komið í ljós að pegar meðferðaraðili leggur mikla áherslu á pátt foreldra í meðferð virðist óviðunandi fjölskylduaðlögun ekki spá fyrir um slakan árangur. ${ }^{40}$ Að lokum spá kipparaskanir ekki fyrir um árangur HAM. ${ }^{38,40,41}$

Ýmsar mismunandi útfærslur á HAM hafa verið rannsakaðar. Til dæmis HAM í hópi. Pær rannsóknir sem eru tiltækar sýna að petta úrræði er jafn áhrifaríkt og hefðbundið einstaklingsmiðað HAM, bæði strax eftir meðferð og einu ári eftir meðferð. ${ }^{25,43}$ Helsti vandinn við hópmeðferð er að fá nægilega mikið og stöðugt flæði sjúklinga pannig að hvert barn purfi ekki að bíða of lengi eftir meðferð. ${ }^{44}$ Petta pýðir að hópmeðferð er kannski betur hægt að framkvæma á stórri meðferðarstöð en lítilli. Annað vandamál er að samband við meðferðaraðila er minna en í einstaklingsmeðferð. Hins vegar eru mögulega einnig kostir við hópúrræði. Til dæmis að hægt er að fylgjast með öðrum gera berskjöldunaræfingar og læra pannig betur um framkvæmdina (modeling). Einnig felast hugsanleg félagsleg áhrif í að gera heimaæfingar og fá umbun fyrir pær frá öðrum. Einnig eru kostir á borð við að vita að annað fólk geti haft svipuð einkenni (normalization) og að pað sé ekki neitt að skammast sín fyrir pó að maður hafi slík einkenni (de-stigmatization). ${ }^{44}$

Hvað með HAM í hópi sem ætlað er sem meðferð við kvíðaröskunum almennt en ekki sérstaklega ÁPR? Á pessu stigi höfum við ekki næga pekkingu til pess að velja á milli. Hins vegar er til nýleg rannsókn á hópúrræðinu Klókum krökkum (Cool Kids) með yfir 1800 pátttakendum, sem sýndi að börn og unglingar með ÁPR höfðu jafnmikinn ávinning af pessari meðferð eins og börn með aðrar kvíðaraskanir. ${ }^{45}$ Við vitum hins vegar ekki hvort Klókir krakkar sé jafn áhrifarík meðferð við einkennum ÁPR og sérhæft HAM.

Fleiri möguleikar eru fyrir hendi til pess að minnka kostnað við meðferð. Almennt má segja að pessar leiðir hafi lítið verið rannsakaðar. Í fyrsta lagi að bjóða upp á meðferð með sjálfshjálparbók sem fyrsta meðferðarprep. ${ }^{46}$ Engar rannsóknir á áhrifum sjálfshjálparbóka meðal barna með ÁPR eru tiltækar. Annar möguleiki er sjálfshjálparforrit (á netinu), með eða án sambands við meðferðaraðila. ${ }^{47}$ Priðji möguleikinn er að bjóða upp á meðferð í gegnum fjarfundarbúnað. Petta gæti orðið góður kostur hér á landi í framtíðinni par sem erfitt er að fá hæfa og reynslumikla meðferðaraðila til að sinna meðferð um allt land. Ein slembivalsrannsókn hefur sýnt að HAM veitt í gegnum skype var árangursríkara en biðlisti. ${ }^{27}$ Einnig hefur komið í ljós með slembivalsrannsókn að HAM veitt í gegnum síma sýndi ekki marktækt lakari árangur en hefðbundið HAM á stofu. ${ }^{48}$ Að lokum má nefna að pað er mögulega breytilegt hversu marga meðferðartíma börn með ÁPR purfi til að hljóta bata. Pannig væri hægt að minnka fjölda tíma og rannsaka hvaða undirhópar ná árangri í styttri meðferð. Pannig sýndi ein rannsókn ekki marktækan mun á 12 vikulegum tímum með HAM og 5 tímum í 12 vikur. En bæði úrræði skiluðu betri árangri en biðlisti. ${ }^{26}$

\section{SRI}

Fyrsta lyfjameðferð er serótónín-endurupptökuhamlandi lyf.,2,19 Pessi hópur inniheldur klómípramín (Anafranil, Klomipramin) sem er príhringlaga geðdeyfðarlyf eða ósérhæft SRI og svo sérhæft SRI (SSRI). Klómípramín er oft talið vera áhrifaríkara en SSRI ( $\mathrm{g}=$ -1,09 samanborið við lyfleysu). ${ }^{12}$ Petta samsvarar pví að í lok meðferðar var meðalpátttakandi sem fékk klómípramín-meðferð með lægra skor á CY-BOCS sem nemur 36 hundraðstölum miðað við meðalpátttakanda í lyfleysu. Flestar rannsóknir á klómípramíni eru hins vegar frá peim tíma pegar minni kröfur voru gerðar um vandaðar rannsóknaraðferðir. Að auki voru flestir pátttakendur í pessum rannsóknum í lyfjameðferð í fyrsta sinn par sem klómípramín var eina tiltæka lyfið. Nú er klómípramín ekki fyrsti kostur fyrir börn með ÁPR vegna algengra og skaðlegra aukaverkana. ${ }^{12}$

SSRI-lyf sem hafa verið sampykkt af bandarísku og evrópsku lyfjastofnunum eru: sertralín (Zoloft, Sertral, Sertralin, Sertraline), ${ }^{4,49}$ flúvoxamín ${ }^{50}$ (ekki aðgengilegt hér á landi flúoxetín (Fontex, Flúoxetín, Seromex) ${ }^{51,52}$ og paroxetín (Seroxat, Paxetin). ${ }^{53}$ Bandaríska lyfjastofnunin hefur gefið út ábendingu fyrir flúvoxamín fyrir 8 ára og eldri (skammtar á bilinu 50-300 mg á dag), flúoxetín fyrir 7 ára og eldri (10-80 mg á dag), og sertralín fyrir 6 ára og eldri (50-200 mg á dag). Paroxetín hefur pó ekki ábendingu 
meðal barna og unglinga með ÁpR.,54 Rannsóknir sem pessar ábendingar byggja á hafa fylgt vönduðum aðferðum, tímalengd viðunandi (10-12 vikur) og viðunandi tímalengd á mögulega virkum skammti (4-6 vikur). Pessar rannsóknir sýna meðaláhrifastærð samanborðið við lyfleysu í tvíblindum samanburðarrannsóknum ( $\mathrm{g}=-0,43)$ með engum muni á milli ólíkra lyfja. ${ }^{12}$ Petta pýðir að í lok meðferðar var meðalpátttakandi í SSRI með lægra CY-BOCSskor sem nemur 16 hundraðstölum miðað við meðalpátttakanda í lyfleysu. Hér á landi hefur Lyfjastofnun eingöngu birt ábendingu fyrir sertralín hjá börnum með ÁPR (6-17 ára). Byrjunarskammtur er 25 mg á dag fyrir 6-12 ára og 50 mg á dag fyrir 13-17 ára. Fyrir börn getur læknir aukið skammtinn í $50 \mathrm{mg}$ eftir eina viku. Hámarksskammtur er 200 mg á dag. ${ }^{55}$ Prátt fyrir ábendingar frá bandarísku og evrópsku lyfjastofnunum hefur Lyfjastofnun ekki gefið út ábendingu um notkun flúoxetín fyrir börn og unglinga með ÁPR.

Klínískar leiðbeiningar mæla með samfelldri notkun á stöðugum skammti i 6-12 mánuði. ${ }^{2}$ Pessar leiðbeiningar byggja til dæmis á rannsókn á sertralíni sem benti til pess að minnst 12 mánaða meðferð sé nauðsynleg og pátttakendur geti vænst pess að ná meiri árangri til langs tíma. ${ }^{57}$ Talið er að börn með ÁPR poli almennt SSRI vel og pessi lyf sýna greinilegan ávinning samanborið við skaðleg áhrif (adverse events) og afleiðingar ómeðhöndlaðs ÁPR. ${ }^{56}$ Algengar aukaverkanir geta pó fylgt meðferð eins og einkenni sem tengjast verkjum eða sjúkdómum í meltingarfærum (lystarleysi, aukin matarlyst, magaverkur, vindgangur) en einnig sjálfsvígshugsanir og tilraunir. ${ }^{2}$ Sjálfsvígshætta er pó tiltölulega lítið vandamál miðað við meðferðarávinning samkvæmt heildargreiningu ${ }^{56}$ og nýlegri rannsókn á mjög stóru úrtaki barna með kvíðaraskanir. ${ }^{58}$ Pó er mikilvægt að fylgjast með hömluleysi (behavioral activation), sérstaklega hjá ungum börnum. ${ }^{59}$

Í nýjustu yfirlitsgreininni sem tiltæk er ${ }^{38}$ um pætti sem spá fyrir um svörun við SSRI kom fram að börn með ÁPR og kipparaskanir eða hegðunarraskanir voru líklegri til pess að svara SSRI verr. Hins vegar eru engin gögn sem styðja að aldur, kyn, byrjunaraldur eða tímalengd ÁPR einkenna spái fyrir um svörun.

\section{HAM, SSRI eða HAM+SSRI sem fyrsta úrræði?}

Beinar samanburðarrannsóknir á HAM og SSRI benda til pess að HAM sé marktækt árangursríkara ${ }^{4,32,33}$ pó að munurinn sé lítill. Rannsóknir benda hins vegar ekki til pess að HAM+SSRI beri meiri árangur en HAM $(\mathrm{g}=-0,13) .{ }^{12}$ Samanburðarrannsóknir á fullorðnum með ÁPR benda til sömu niðurstaðna. ${ }^{60}$ Pættir sem snúa að reynslu og hæfni gætu skipt máli varðandi byrjunarmeðferð. Í stærstu slembivalsrannsókninni á HAM og SSRI sem til er ${ }^{4}$ kom í ljós mikill munur eftir meðferðarstöðum. Pannig var árangur HAM mun meiri í Háskólanum í Pennsylvaníu, par sem mjög margir hæfir meðferðaraðilar starfa, miðað við árangur HAM í Duke-háskóla, par sem meðferðaraðilar voru ekki jafn reynslumiklir. Nánar tiltekið sýndi HAM jafn mikinn árangur og HAM+SSRI en meiri en SSRI í Pennsylvaníu, en í Duke sýndi HAM marktækt minni árangur en HAM+SSRI. Petta bendir til pess að ef hæfni meðferðaraðila í að veita HAM er næg bæti pað ekkert við árangurinn pó að barnið sé einnig meðhöndlað með SSRI. Ef hæfni meðferðaraðila í HAM er hins vegar lítil, er nauðsynlegt að bæta við SSRI til að ná fram sama árangri.

Klínískar leiðbeiningar bandaríska barnageðlæknafélagsins mæla alltaf með HAM+SSRI ef einkenni eru alvarleg. Pessi tilmæli eru í andstöðu við evrópsk tilmæli og virðast ekki vera byggð á raungögnum heldur klínískri reynslu. Eins og áður var nefnt spá alvarleg einkenni í upphafi meðferðar fyrir um slakari árangur, óháð pví hvaða meðferð er veitt (HAM, SSRI eða HAM+SSRI). Börn sem fá HAM+SSRI hafa með öðrum orðum ekki sýnt fram á marktækt betri árangur en börn sem fá eingöngu HAM eða SSRI. ${ }^{39}$

Pó að SSRI bæti litlu eða engu við HAM benda rannsóknir til að HAM+SSRI sé marktækt árangursríkara en SSRI eitt og sér, ${ }^{4,61}$ samanlagt er áhrifastærðin $(\mathrm{g}=-0,59) .{ }^{12}$ Petta pýðir að meðalpátttakandi í HAM+SSRI sé með lægra skor á CY-BOCS sem svarar 22 hundraðstölum. Sú heildargreining á samanburðarrannsóknum meðal fullorðinna og barna með ÁPR sem nefnd var hér að ofan bendir einnig til pess að HAM+SSRI skili meiri árangri en SSRI eitt og sér. ${ }^{60}$

Hvernig meðferð er veitt hér á landi? Í könnun sem gerð var meðal barna- og unglingageðlækna hér á landi $(n=7)$ voru prír sem völdu venjulega SSRI-meðferð eingöngu sem fyrstu meðferð en fjórir vildu helst byrja með sálfræðimeðferð. Tveir af peim vildu jafnframt meðhöndla börnin með SSRI en einn til viðbótar kaus að bæta SSRI við einungis ef einkenni voru mjög hamlandi. Sex peirra nefndu pó að aldur barnanna skipti máli varðandi SSRImeðferð, pannig voru mun meiri líkur á að sálfræðimeðferð ein og sér væri fyrsti meðferðarkostur ef börnin voru undir 10 ára aldri og væri beitt aðeins sálfræðimeðferð ef börnin voru undir 6 ára aldri.

\section{Börn sem svara fyrstu meðferð illa}

Ef hefðbundin HAM hefur ekki reynst árangursrík benda klínískar leiðbeiningar til að halda eigi áfram með HAM en bæta SSRI við.,19 Hins vegar eru pessi tilmæli aðeins byggð á áliti sérfræðinga en ekki raungögnum. Valmöguleikarnir eru nokkrir: 1) Halda áfram með HAM, 2) Halda áfram með HAM en bæta SSRI við, 3) hætta með HAM og skipta yfir í SSRI. Aðeins er til ein rannsókn sem hefur prófað tvö af pessum premur úrræðum í hópi barna sem enn höfðu umtalsverð einkenni eftir 14 vikulega HAM-tíma. Pessi rannsókn var hluti af norrænu verkefni par sem 269 börn fengu HAM sem fyrstu meðferð. ${ }^{5}$ Pau sem enn höfðu miðlungs til alvarleg einkenni fengu af handahófi annaðhvort áframhaldandi HAM, 10 tíma í 16 vikur, eða sertralín (16 vikur). Enginn munur kom í ljós eftir meðferð. Hins vegar minnkuðu einkenni umtalsvert í báðum hópum. ${ }^{62}$ Í sömu rannsókn kom einnig í ljós að börn með ÁPR og kipparöskun sem fengu sertralín sýndu betri árangur en pau sem héldu áfram með HAM, en enginn munur var á hópum meðal barna sem ekki höfðu kipparöskun. ${ }^{63}$ Einnig má spyrja hvort árangurs sé af vænta af SSRI hjá börnum sem hafa fengið tvöfalda meðferð með HAM (14+10 tíma). Nýleg opin rannsókn sýndi að aðeins sum börn gætu vænst góðrar svörunar (18\%). ${ }^{64}$

Klínískar leiðbeiningar mæla með að skipt sé yfir í annað SSRI hjá börnum sem ekki svara fyrsta SSRI., ${ }^{2,19}$ Rannsóknargögn eru hins vegar af skornum skammti. ${ }^{2}$ Í meðferðarrannsókn á kvíða- 
röskunum (ekki ÁPR) meðal barna reyndist vel að skipta úr flúvoxamíni í flúoxetín. ${ }^{65}$ Annað ráð er að bæta klómípramíni við.,19 Hugmyndin á bak við petta er að sameina serótónvirk áhrif hvers lyfs en að minnka eins og mögulegt er aukaverkanir hvers lyfjaflokks. Mikilvægt er að fylgjast vel með hvort hjartsláttartruflanir komi fram pegar klómípramín er notað. Pegar pað er notað ásamt SSRI parf að sýna enn meiri varkárni par sem aukin serótónvirk eitrunaráhrif geta komið fram. Hins vegar er mikilvægt að áhættan sé vegin miðað við mögulegan skaða af ómeðhöndluðum einkennum. ${ }^{2,66}$ Rannsóknargögn um pessa aðferð eru afar takmörkuð. Meðal barna með ÁPR hafa eingöngu verið birtar niðurstöður um sjúkratilfelli. Hvað einkenni varðar náðu pátttakendur árangri en skaðleg áhrif, og pá sérstaklega hjartsláttartruflanir, voru einnig greinileg. 67,68 Meðal fullorðinna með ÁPR finnst ein tvíblind slembivalsrannsókn sem sýndi árangur klómípramín+fluoxetín umfram quetiapine+flúoxetín meðal sjúklinga sem ekki höfðu svarað SSRI. Hins vegar var enginn munur milli hópa sem fengu klómípramín+flúoxetín eða lyfleysu+fluoxetín. Petta bendir til pess að pað sé betra að halda áfram meðferð með SSRI í lengri tíma (best með hámarksskammti) áður en meðferð með klómípramíni er prófuð. ${ }^{69}$

Takmarkað aðgengi að HAM er víða alvarlegt vandamál. Petta pýðir að á mörgum stöðum í heiminum fá börn og unglingar með ÁPR eingöngu SSRI-meðferð. ${ }^{36}$ Fyrir börn sem ekki svara SSRI og ekki hafa verið meðhöndluð með HAM er mun árangursríkara að meðhöndla með HAM+SSRI ef kostur er frekar en að halda áfram meðferð með SSRI eingöngu. ${ }^{70}$

\section{Úrræði fyrir meðferðarbolið ÁpR}

Við skilgreinum pað sem meðferðarpolan ÁPR pegar börn hafa hvorki svarað HAM né SSRI (tvær tilraunir). Fyrir pennan hóp mæla klínískar leiðbeiningar með viðbótarlyfjameðferð eða daglegum tímum með HAM (intensive CBT), ${ }^{2,19}$ Rannsóknir á daglegum HAM-tímum eru takmarkaðar. Prjár opnar rannsóknir hafa verið gerðar sem sýna fram á árangur meðal barna með meðferðarpolna ÁPR.71-73 Ein slembivalsrannsókn sýndi að daglegir tímar í prjár vikur gætu borið meiri árangur, par sem fleiri börn svöruðu meðferðinni eða náðu bata. ${ }^{74}$

Viðbótarlyfjameðferð felur í sér notkun á öðrum lyfjum en SSRI sem kunna að bæta árangur með annars konar verkun/verkun á boðefni önnur en serótónín. Taugafræðilegar rannsóknir sýna að auk serótóníns eru fleiri taugaboðefni sem kunna að koma við sögu i ÁPR, eins og glútamat ${ }^{17}$ og dópamín. ${ }^{18}$ Rannsóknargögn eru hins vegar af skornum skammti. Notkun peirra hefur ekki verið viðurkennd, hvorki af bandarísku né evrópsku lyfjastofnununum.

\section{Annarrar kynslóðar geðrofslyf}

Ein algengasta viðbótarmeðferð fyrir ÁPR eru annarrar kynslóðar geðrofslyf (atypical antipsychotics). Virkni peirra tengist hömlun á viðtökum dópamíns. Tvíblindar slembivalsrannsóknir hafa verið gerðar meðal fullorðinna með ÁPR sem sýna fram á árangur risperidón (Risperdal, Ríson, Risperidón, Risperidon), aripiprasól (Abilify, Lemilvo, Aripiprazol, Aripiprazole), quetiapine (Seroquel,
Quetiapin, Quetiapine), olanzapine (Zyprexa, Zyprexa Velotab, Kozylex, Lazapix, Zalasta) og haloperidol (haldol) (fyrstu kynslóðar geðrofslyf). ${ }^{18,75}$ Meðal fullorðinna með ÁpR eru áhrif pessara lyfja meiri hjá peim sem hafa kipparöskun sem fylgiröskun. ${ }^{75}$ Meðal barna með ÁPR finnast engar samanburðarrannsóknir. Pað er ekki sjálfsagt mál að álykta að pessi lyf hafi sömu áhrif á börn. Til pess parf að líta svo á að einkennamynd ÁPR sé ekki bara eins meðal barna og fullorðinna, heldur einnig boðefnakerfi, en hjá börnum er boðefnakerfið ekki fullproskað eins og hjá fullorðnum. ${ }^{76}$ Einu rannsóknirnar sem eru tiltækar meðal barna með ÁPR eru raunlýsandi rannsóknir (naturalistic) á notkun risperidón og aripiprasól til viðbótar við SSRI og benda pær niðurstöður til árangurs. ${ }^{77-80}$ Til að mynda komu í ljós í einni samanburðarrannsókn (ekkert slembival) á börnum með ÁPR og kipparöskun (n=69) svipuð jákvæð áhrif af risperidón og aripiprasól. Hins vegar voru alvarlegar aukaverkanir af risperidón mun meiri. Petta voru aukaverkanir á borð við alvarlegar efnaskiptabreytingar, pyngdaraukningu og óæskileg róandi áhrif (sedation) en aripiprasól hafði frekar í för með sér vægt/miðlungs hömluleysi. ${ }^{77}$ Rannsóknir á sjúkratilfellum sýna einnig árangur af meðferð með risperidón. ${ }^{81-83}$ Margir pátttakendur í pessum rannsóknum höfðu hins vegar aldrei verið meðhöndlaðir með HAM og pví ekki víst að ávinningur af risperidón hefði verið jafn mikill ef peir sem svara eða fá bata með HAM hefðu verið teknir út úr rannsókninni. Nýleg tvíblind slembivalsrannsókn á fullorðnum með ÁpR sem ekki svöruðu SSRI (höfðu aldrei fengið HAM) sýndi að peir sem voru valdir af handahófi í SSRI+HAM svöruðu mun betur en peir sem héldu áfram með SSRI en fengu risperidón til viðbótar. ${ }^{84}$ Pannig að með pví að taka bæði mögulegan ávinning og skaðleg áhrif til greina pá mælum við með að annarrar kynslóðar geðrofslyf verði ekki notuð meðal barna með ÁpR án pess að búið sé að prófa HAM (með viðunandi hætti og með hæfum meðferðaraðila) og SSRI (tvær tilraunir). Áhættuna af ómeðhöndluðum og alvarlegum einkennum parf að vega á móti mögulegum skaðlegum áhrifum pessara lyfja. Við mælum með pví að fylgja ráðleggingum sérfræðinga. ${ }^{85}$

\section{Önnur lyfjameðferð}

Aðrar mögulegar meðferðarleiðir fyrir meðferðarpolið ÁpR ${ }^{2}$ eru örvandi lyf (stimulants), gabapentín, súmatriptan, píndólól, morfín, tramadól, anfranal, inósítól, ípiöt, Jóhannesarjurt (St. John's wort), $\mathrm{N}$-acetylcysteine ${ }^{86}$ og glútamat-mótlyf (glutamate antagonists) á borð við memantín (Memantine) og rílúsól (riluzole) 107). ${ }^{87}$ Einnig hafa komið fram hugmyndir um mögulegan ávinning af pví að skipta í serótónín-noradrenalín endurupptökuhamla (SNRI) (venlafaxín og dúloxetín). Tvíblindar slembivalsrannsóknir meðal fullorðinna benda pó ekki til pess að venlafaxín sé áhrifaríkara en paroxetín (SSRI). ${ }^{88}$ I framhaldsrannsókn á sömu sjúklingum sem ekki svöruðu meðferð kom í ljós betri árangur ef skipt var úr venlafaxíni í paroxetín en ef skipt var úr paroxetíni í venlafaxín. ${ }^{89}$ Hins vegar er mögulegt að serótónín-tengd gen spái fyrir um hvaða sjúklingar svari SSRI/SNRI.90 Önnur meðferðarleið sem hefur verið reynd meðal fullorðinna er að auka SSRI-skammtinn meira en sem nemur ráðlögðum dagsskammti. Ein tvíblind slembivalsrannsókn meðal fullorðinna með ÁPR sem ekki höfðu svarað SSRI sýndi að 
ávinningurinn var mun meiri með pví að auka sertralínskammt í 400 mg miðað við 200 mg á dag. ${ }^{91}$ Mikilvægt er að nefna aftur að öll pessi meðferðarúrræði eru án ábendinga og aðeins takmörkuð rannsóknargögn búa að baki. ${ }^{2}$ Eitt úrræði án ábendingar sem hefur verið rannsakað að nokkru leyti er að bæta mótefni fyrir serótónín 5-HT3 tauganema við SSRI-meðferð (graníetrón og ondansetrón Ondansetron). ${ }^{92}$ Ein tvíblind slembivalsrannsókn benti til ávinnings við að bæta granisetrón við SSRI meðal fullorðinna með ÁPR (93) og tvær tvíblindar slembivalsrannsóknir bentu til pess að sama aðferð með ondansetrón gæfi greinilegan ávinning. ${ }^{94,95}$ Vert er að nefna enn og aftur að pessum úrræðum á að beita í samvinnu við sérfræðinga og aðeins með börnum sem hvorki hafa svarað HAM né SSRI.

Notkun á bensódíasepín (benzodiazepines) eins og klónasepam (clonazepam) er ekki viðurkennd af bandaríka lyfjastofnuninni og pví fylgir aukin áhætta. ${ }^{2}$ Aðeins finnst eitt sjúkratilfelli meðal barna með ÁPR sem sýndi ávinning af flúoxetíni og benzodazepíni. ${ }^{96}$ Tvær tvíblindar slembivalsrannsóknir finnast meðal fullorðinna með ÁPR sem sýndu ekki neinn ávinning af klónasepam pegar pví var bætt við SSRI. ${ }^{97,98}$ Miðað við núverandi pekkingu er ekki mælt með pessari meðferð.

\section{Samantekt}

Í pessari grein höfum við lýst stöðu meðferðarúrræða fyrir prjá ólíka hópa barna með ÁPR, 1) ómeðhöndlaða ÁPR, 2) börn sem hafa verið meðhöndluð einu sinni eða oftar með fyrsta úrræði (HAM eða SSRI) en svarað pví illa og 3) meðferðarpolin ÁpR. Almennt má segja að rannsóknarniðurstöður séu í samræmi við klínískar leiðbeiningar og pá sérstaklega evrópskar leiðbeiningar. ${ }^{19,99}$

Fyrir börn sem ekki hafa verið meðhöndluð áður, benda rannsóknarniðurstöður sterklega til pess að pegar aðgengi er að kunnáttufólki í HAM, eigi HAM ein og sér að vera fyrsti meðferðarkostur og að HAM ein og sér sé jafn árangursrík og HAM+SSRI pegar reynslumiklir HAM meðferðaraðilar veita meðferðina.,100 Pegar ekki er aðgengi að sérfræðingum er líklegt að SSRI til viðbótar eða eitt og sér sé mikilvægt. Nýleg norræn rannsókn bendir pó til pess að mögulegt sé að pjálfa meðferðaraðila til pess að veita góða HAM-meðferð með sama árangri og á sérhæfðum meðferðarstöðum. ${ }^{5}$

Rannsóknir á börnum sem ekki hafa svarað fyrstu meðferð eru takmarkaðar og niðurstöðum ber að taka með fyrirvara par til frekari gögn liggja fyrir. Helstu meðferðarleiðir fyrir börn sem hafa verið meðhöndluð með HAM án svörunar eru: 1) halda áfram með HAM, 2) hætta HAM og byrja með SSRI, 3) halda áfram með HAM og einnig bæta við SSRI. Aðeins ein rannsókn er til á pessum hópi sem benti til pess að pað væri jafn árangursríkt að 1) halda áfram með HAM og að 2) skipta yfir í SSRI. ${ }^{62}$ Helsta meðferðarleiðin fyrir börn sem hafa verið meðhöndluð með SSRI með takmarkaðri svörun er að skipta um SSRI. Hins vegar liggja engin raungögn fyrir um pessa leið. Ef ekki er búið að bjóða upp á HAM og sá möguleiki er fyrir hendi, benda rannsóknir til pess að pað gæti skilað mun meiri árangri umfram áframhaldandi SSRImeðferð..$^{70}$

Rannsóknargögn fyrir meðferðarpolið ÁPR eru mjög takmörkuð. Раð er nauðsynlegt að rannsaka pennan hóp sérstaklega. Раð er meðal annars sár pörf á nýjum lyfjategundum sem eru áhrifaríkari en SSRI. Sérstaklega í ljósi aukins skilnings á taugalíffræði og taugaefnafræði. Раð meðferðarúrræði sem er líklega mest notað hér á landi á eftir HAM og SSRI eru annarrar kynslóðar geðrofslyf. Pessi lyf hafa í för með sér umtalsverð skaðleg áhrif og á pessari stundu er ekki vitað hvort kostirnir við slíka meðferð vegi upp á móti pessum skaðlegu áhrifum. Við mælum með pví að pessi lyf verði aðeins notuð af sérfræðingum. Einnig parf að rannsaka betur árangur daglegrar HAM-meðferðar.

ENGLISH SUMMARY

\section{A Review and Recommendations of Evidence-Based Treatments for Pediatric Obsessive-Compulsive Disorder}

Guðmundur Skarphéðinsson', Bertrand Lauth ${ }^{2,3}$, Urður Njarðvík ${ }^{4}$, Tord Ivarsson ${ }^{1}$

Pediatric obsessive-compulsive disorder (OCD) is characterized by recurrent obsessions and compulsions. In this review we depict evidence-based treatments for pediatric OCD patients. We searched PubMed for relevant publications including randomized controlled trials, reviews, and expert guidelines. Substantial evidence for cognitive behavior therapy (CBT) and specific serotonin reuptake inhibitors (SSRIs) among treatment-naïve patients shows that both treatments are effective. CBT is significantly more effective than SSRI based on head-to-head trials. The evidence for CBT- or SSRI-resistant patients is limited but indicates that CBT and SSRI are effective treatments for CBT non-responders while a combination of CBT and SSRI is the most effective treatment for SSRI non-responders with no prior exposure to CBT. The current data support clinical guidelines indicating that when CBT expertise is present, one can successfully treat patients with CBT. CBT is also as effective as SSRI in non-responders after 14 weeks of CBT. The results did not indicate that combined treatment of CBT and SSRI is more effective than CBT delivered by experts. However, combined treatment is more effective than SSRI in SSRI non-responders.

${ }^{1}$ Center for Child and Adolescent Mental Health, Eastern and Southern Norway, ${ }^{2}$ University of Iceland, Faculty of Medicine, ${ }^{3}$ Landspitali - The University Hospital of Iceland, ${ }^{4}$ University of Iceland, Faculty of Psychology.

Key words: Obsessive-compulsive disorder, children and adolescents, treatment, Cognitive behavior therapy, selective serotonin reuptake inhibitors, atypical antipsychotics, treatment-resistant, treatment-refractory.

Correspondence: Guðmundur Skarphéðinsson, gudmundur.skarphedinsson@r-bup.no 


\section{Heimildir}

\section{Læknablaðið birtir í blaðinu heimildalista við yfirlitsgreinar með allt að 60 heimildum} - lengri listi er birtur við greinina á heimasíðu blaðsins.

1. American Psychiatric Association. Diagnostic and Statistical Manual of Mental Disorders, Fifth Edition (DSM-5(TM)). American Psychiatric Publishing Arlington, VA 2013.

2. Geller D, March J. Practice parameter for the assessmen and treatment of children and adolescents with obsessive-compulsive disorder. J Am Acad Child Adolesc Psychiatry 2012; 51: 98-113.

3. Ivarsson T, Melin K, Wallin L. Categorical and dimensional aspects of co-morbidity in obsessive-compulsive disorder (OCD). Eur Child Adolesc Psychiatry 2008; 17: 20-31.

4. POTS Study Team. Cognitive-behavior therapy, sertraline, and their combination for children and adolescents with obsessive-compulsive disorder: the Pediatric OCD Treatment Study (POTS) randomized controlled trial. JAMA 2004; 292: 1969-76.

5. Torp NC, Dahl $K$, Skarphedinsson $G$, Thomsen $P$, Valderhaug R, Weidle B, et al. Effectiveness of cognitive behavior treatment for pediatric obsessive-compulsive disorder: Acute outcomes from The Nordic Long-term OCD Treatment Study (NordLOTS). Behav Res Ther 2015; 64: $15-23$

6. Bloch $\mathrm{MH}$, Landeros-Weisenberger A, Rosario $\mathrm{MC}$ Pittenger C, Leckman JF. Meta-analysis of the symptom structure of obsessive-compulsive disorder. Am Psychiatry 2008; 165: 1532-42.

7. Piacentini J, Bergman RL, Chang S, Langley A, Peris T, Wood JJ, et al. Controlled comparison of family cognitive behavioral therapy and psychoeducation/relaxation training for child obsessive-compulsive disorder. J Am Acad Child Adolesc Psychiatry 2011; 50: 1149-61.

8. Stewart SE, Geller DA, Jenike M, Pauls D, Shaw D, Mullin B, et al. Long-term outcome of pediatric obsessive-compulsive disorder: a meta-analysis and qualitative review of the literature. Acta Psychiatr Scand 2004; 110: $4-13$

9. Micali N, Heyman I, Perez M, Hilton K, Nakatani E, Turner C, et al. Long-term outcomes of obsessive-compulsive disorder: follow-up of 142 children and adolescents. Br J Psychiatry 2010; 197: 128-34.

10. Jenike MA, Rauch SL. Managing the patient with treatment-resistant obsessive compulsive disorder: current strategies. J Clin Psychiatry 1994; 55 Suppl:11-7.

11. Skarphedinsson G, Hanssen-Bauer $\mathrm{K}$, Kornor $\mathrm{H}$, Heiervang ER, Landro NI, Axelsdottir B, et al. Standard individual cognitive behaviour therapy for paediatric obsessive-compulsive disorder: A systematic review of effect estimates across comparisons. Nord J Psychiatr 2015; 69: 81-92.

12. Ivarsson $T$, Skarphedinsson $G$, Kornor $H$, Axelsdottir $B$, Biedilae S, Heyman I, et al. The place of and evidence for serotonin reuptake inhibitors (SRIs) for obsessive compulsive disorder (OCD) in children and adolescents: Views based on a systematic review and meta-analysis. Psychiatry Res 2015; 227: 93-103.

13. Bloch MH, Storch EA. Assessment and Management of Treatment-Refractory Obsessive-Compulsive Disorder in Children. J Am Acad Child Adolesc Psychiatry 2015; 54 251-62.

14. Sánchez-Meca J, Rosa-Alcázar AI, Iniesta-Sepúlveda M, Rosa-Alcázar Á. Differential efficacy of cognitive -behavioral therapy and pharmacological treatments for pediatric obsessive@compulsive disorder: A meta-analysis. J Anxiety Disord 2014; 28: 31-44.

15. Pittenger $\mathrm{C}$, Bloch $\mathrm{MH}$. Pharmacological treatment of obsessive-compulsive disorder. Psychiatr Clin North Am 2014; 37: 375-91

16. Freeman $\mathrm{J}$, Garcia A, Frank $\mathrm{H}$, Benito $\mathrm{K}$, Conelea $\mathrm{C}$ Walther $\mathrm{M}$, et al. Evidence base update for psychosocial treatments for pediatric obsessive-compulsive disorder. J Clin Child Adolesc Psychol 2014; 43: 7-26.

17. Grados MA, Specht MW, Sung HM, Fortune D. Glutamate drugs and pharmacogenetics of OCD: a pathway-based exploratory approach. Exp Opin Drug Discov 2013; 8 : 1515-27.
18. Dold M, Aigner $\mathrm{M}$, Lanzenberger $\mathrm{R}$, Kasper $\mathrm{S}$. Antipsychotic augmentation of serotonin reuptake inhibitors in treatment-resistant obsessive-compulsive disorder: a meta-analysis of double-blind, randomized, placebo-controlled trials. Int J Neuropsychopharmacol 2013; 16: 557-74

19. National Institute for Heath and Clinical Excellence. Obsessive compulsive disorder (OCD) and body dysmorphic disorder (BDD) London: National Institute for Health and Clinical Excellence; 2005. guidance.nice. org.uk/CG31 - janúar 2016.

20. Peris TS, Compton S, Piacentini J. Trajectories of change in cognitive behavior therapy for pediatric anxiety. AACAP 59th Annual Meeting; October 23, 2012; San Francisco 2012.

21. Bolton D, Perrin S. Evaluation of exposure with response-prevention for obsessive compulsive disorder in childhood and adolescence. J Behav Ther Exp Psychiatry 2008; 39: 11-22.

22. March J, Frances A, Carpenter D, Kahn DA. Treatment of obsessive-compulsive disorder. The Expert Consensus Panel for obsessive-compulsive disorder. J Clin Psychiatry 1997; 58 Suppl 4:2-72.

23. March JS, Mulle K. OCD in Children and Adolescents: A cognitive-behavioral treatment manual. Guilford Press, New York 1998.

24. Foa EB. Cognitive behavioral therapy of obsessive-compulsive disorder. Dialogues Clin Neurosci 2010; 12: 199-207.

25. Barrett P, Healy-Farrell L, March JS. Cognitive-behavioral family treatment of childhood obsessive-compulsive disorder: a controlled trial. J Am Acad Child Adolesc Psychiatry 2004; 43: 46-62.

26. Bolton D, Williams T, Perrin S, Atkinson L, Gallop C, Waite $\mathrm{P}$, et al. Randomized controlled trial of full and brie cognitive-behaviour therapy and wait-list for paediatric obsessive-compulsive disorder. J Child Psychol Psychiatr 2011; 52: 1269-78

27. Storch EA, Caporino NE, Morgan JR, Lewin AB, Rojas A, Brauer L, et al. Preliminary investigation of web-camera delivered cognitive-behavioral therapy for youth with obsessive-compulsive disorder. Psychiatry Res 2011; 189: $407-12$.

28. Williams TI, Salkovskis PM, Forrester L, Turner S, White $\mathrm{H}$, Allsopp MA. A randomised controlled trial of cognitive behavioural treatment for obsessive compulsive disorder in children and adolescents. Eur Child Adolesc Psychiatry 2010; 19: 449-56.

29. Lewin AB, Park JM, Jones AM, Crawford EA, De Nada AS, Menzel J, et al. Family-based exposure and response prevention therapy for preschool-aged children with obsessive-compulsive disorder: A pilot randomized controlled trial. Behav Res Ther 2014; 56: 30-8.

30. Freeman JB, Garcia AM, Coyne L, Ale C, Przeworsk A, Himle M, et al. Early childhood OCD: preliminary findings from a family-based cognitive-behavioral approach. J Am Acad Child Adolesc Psychiatry 2008; 47: 593602

31. Freeman J, Sapyta J, Garcia A, Compton S, Khann M, Flessner C, et al. Family-based treatment of early childhood obsessive-compulsive disorder: the Pediatric Obsessive-Compulsive Disorder Treatment Study for Young Children (POTS Jr)--a randomized clinical trial. JAMA Psychiatry 2014; 71: 689-98

32. de Haan E, Hoogduin KA, Buitelaar JK, Keijsers GP. Behavior therapy versus clomipramine for the treatment of obsessive-compulsive disorder in children and adolescents. J Am Acad Child Adolesc Psychiatry 1998; 37: $1022-9$

33. Asbahr FR, Castillo AR, Ito LM, Latorre MRDdO, Moreira MN, Lotufo-Neto F. Group cognitive-behavioral therapy versus sertraline for the treatment of children and adolescents with obsessive-compulsive disorder. J Am Acad Child Adolesc Psychiatry 2005; 44: 1128-36.

34. Scahill L, Riddle MA, McSwiggin-Hardin M, Ort SI, King RA, Goodman WK, et al. Children's Yale-Brown Obsessive Compulsive Scale: reliability and validity. J Am Acad Child Adolesc Psychiatry 1997; 36: 844-52.
35. Cohen J. Statistical power analysis for the behavioral sciences. rev. ed. Lawrence Erlbaum Associates. Hillsdale, NJ 1977

36. Franklin ME, Dingfelder HE, Coogan CG, Garcia AM, Sapyta JJ, Freeman JL. Cognitive behavioral therapy for pediatric obsessive-compulsive disorder: development of expert-level competence and implications for dissemination. J Anxiety Disord 2013; 27: 745-53.

37. Sjúkratryggingar Íslands. Sálfræđibjónusta 2016 sjukra.is/ heilbrigdisthjonusta/salfraedithjonusta-vid-born/ - janúar 2016.

38. Ginsburg GS, Kingery JN, Drake KL, Grados MA Predictors of treatment response in pediatric obsessive-compulsive disorder. J Am Acad Child Adolesc Psychiatry 2008; 47: 868-78.

39. Garcia AM, Sapyta JJ, Moore PS, Freeman JB, Franklin ME, March JS, et al. Predictors and moderators of treatment outcome in the Pediatric Obsessive Compulsive Treatment Study (POTS I). J Am Acad Child Adolesc Psychiatry 2010; 49: 1024-33; quiz 86 .

40. Torp NC, Dahl K, Skarphedinsson G, Thomsen PH, Valderhaug R, Weidle B, et al. Predictors associated with improved cognitive-behavioral therapy outcome in pediatric obsessive-compulsive disorder. J Am Acad Child Adolesc Psychiatry 2015; 54: 200-7.

41. Storch EA, Merlo LJ, Larson MJ, Geffken GR, Lehmkuhl $\mathrm{HD}$, Jacob ML, et al. Impact of comorbidity on cognitive-behavioral therapy response in pediatric obsessive-compulsive disorder. J Am Acad Child Adolesc Psychiatry 2008; 47: 583-92.

42. Merlo LJ, Lehmkuhl HD, Geffken GR, Storch EA. Decreased family accommodation associated with improved therapy outcome in pediatric obsessive-compulsive disorder. J Consult Clin Psychol 2009; 77: 355-60.

43. Barrett $\mathrm{P}$, Farrell $\mathrm{L}$ Dadds $\mathrm{M}$, Boulter N. Cognitivebehavioral family treatment of childhood obsessive-compulsive disorder: long-term follow-up and predictors of outcome. J Am Acad Child Adolesc Psychiatry 2005; 44: 1005-14.

44. Himle JA, Van Etten M, Fischer DJ. Group Cognitive Behavioral Therapy for Obsessive-Compulsive Disorder: A Review. Brief Treatment and Crisis Intervention 2003; 3: 217-29.

45. Hudson JL, Rapee RM, Lyneham HJ, McLellan LF, Wuthrich VM, Schniering CA. Comparing outcomes for children with different anxiety disorders following cognitive behavioural therapy. Behav Res Ther 2015; 72: 30-7.

46. Tolin DF, Diefenbach GJ, Gilliam CM. Stepped care versus standard cognitive-behavioral therapy for obsessive-compulsive disorder: A preliminary study of efficacy and costs. Depress Anxiety 2011; 28: 314-23.

47. Lenhard F, Vigerland S, Andersson E, Ruck C, Mataix-Cols $\mathrm{D}$, Thulin U, et al. Internet-delivered cognitive behavior therapy for adolescents with obsessive-compulsive disorder: an open trial. PLoS ONE 2014; 9: e100773.

48. Turner CM, Mataix-Cols D, Lovell K, Krebs G, Lang K, Byford S, et al. Telephone Cognitive-Behavioral Therapy for Adolescents With Obsessive-Compulsive Disorder: A Randomized Controlled Non-inferiority Trial. J Am Acad Child Adolesc Psychiatry 2014; 53: 1298-307.e2.

49. March JS, Biederman J, Wolkow R, Safferman A, Mardekian J, Cook EH, et al. Sertraline in children and adolescents with obsessive-compulsive disorder: a multicenter randomized controlled trial. JAMA 1998; 280: 1752-6

50. Riddle MA, Reeve EA, Yaryura-Tobias JA, Yang HM, Claghorn JL, Gaffney G, et al. Fluvoxamine for children and adolescents with obsessive-compulsive disorder: a randomized, controlled, multicenter trial. J Am Acad Child Adolesc Psychiatry 2001; 40: 222-9.

51. Riddle MA, Scahill L, King RA, Hardin MT, Anderson GM, Ort SI, et al. Double-blind, crossover trial of fluoxetine and placebo in children and adolescents with obsessive-compulsive disorder. J Am Acad Child Adolesc Psychiatry 1992; 31: 1062-9. 
52. Geller DA, Hoog SL, Heiligenstein JH, Ricardi RK, Tamura $\mathrm{R}$, Kluszynski S, et al. Fluoxetine treatment for obsessive-compulsive disorder in children and adolescents: a placebo-controlled clinical trial. J Am Acad Child Adolesc Psychiatry 2001; 40: 773-9. mrw.interscience.wiley.com/ cochrane/clcentral/articles/203/CN-00349203/frame.html janúar 2016.

53. Geller DA, Wagner KD, Emslie G, Murphy T, Carpenter DJ, Wetherhold E, et al. Paroxetine treatment in children and adolescents with obsessive-compulsive disorder: a randomized, multicenter, double-blind, placebo-controlled trial. J Am Acad Child Adolesc Psychiatry 2004; 43: 1387-96.

54. Walsh KH, McDougle CJ. Psychotherapy and medication management strategies for obsessive-compulsive disorder. Neuropsychiatr Dis Treat 2011; 7: 485-94.
55. Lyfjastofnun. Sertralin Bluefish Reykjavik: Lyfjastofnun 2013. serlyfjaskra.is. - janúar 2016.

56. Bridge JA, Iyengar $S$, Salary $C B$, Barbe RP, Birmaher B, Pincus HA, et al. Clinical response and risk for reported suicidal ideation and suicide attempts in pediatric antidepressant treatment: a meta-analysis of randomized controlled trials. JAMA 2007; 297: 1683-96.

57. Wagner KD, Cook EH, Chung H, Messig M. Remission status after long-term sertraline treatment of pediatric obsessive-compulsive disorder. J Child Adolesc Psychopharmacol 2003; 13 Suppl 1: S53-60.

58. Rynn MA, Walkup JT, Compton SN, Sakolsky DJ, Sherrill JT, Shen S, et al. Child/Adolescent anxiety multimodal study: evaluating safety. J Am Acad Child Adolesc Psychiatry 2015; 54: 180-90.
59. Offidani E, Fava GA, Tomba E, Baldessarini RJ. Excessive mood elevation and behavioral activation with antidepressant treatment of juvenile depressive and anxiety disorders: a systematic review. Psychother Psychosom 2013; 82: 132-41.

60. Romanelli RJ, Wu FM, Gamba R, Mojtabai R, Segal JB. Behavioral therapy and serotonin reuptake inhibitor pharmacotherapy in the treatment of obsessive-compulsive disorder: A systematic review and meta-analysis of head-to-head randomized controlled trials. Depress Anxiety 2014; 31: 641-52. 